\title{
Framework for the Involvement of Citizens in Urban Renewal Programmes; an Outcome of Coal Camp Upgrading Action Plan Experience in Enugu City, Nigeria
}

\author{
Dr. Ben. O. Uwadiegwu, mnitp, rtp., Dr. Edmund A. Iyi \\ Department of Environmental Management Nnamdi Azikiwe University, Awka, Nigeria. \\ Department of Urban and Regional Planning Enugu State University of Science and Technology, Enugu, \\ Nigeria.
}

\begin{abstract}
The stories of urban renewal in Nigeria are that of unsuccessful attempts because all of them met with cataclysmic failure due to the fact that each was frustrated by residents' upheaval and stubborn resistance. An impression was thus created that urban renewal is a mission impossible which cannot be successfully carried out without opposition. The aim of this paper is to provide a pragmatic urban renewal framework which could be adopted to surmount the stakeholders and residents induced frictions and resistance that often constrain urban renewal programmes in Nigeria. Coal Camp Community urban renewal studies undertaken in Enugu City as part of Ph.D programme provided data base for the articulation of procedural framework for the involvement of the citizens during urban renewal programmes. Initially the residents were opposed to the urban renewal proposals but after series of sensitization, enlightenment and consultations, they changed their opinion and not only co-operated and supported the programme but ready to commit their resources to it. Chi-square $\left(X^{2}\right)$ model was used as analytical tool to find out their reasons for opposition. Those reasons were used as inputs in designing sensitization and enlightenment programmes. This takes into account the human resource dimensional issues which need to be invested in urban renewal programmes for the satisfaction of all. Adoption of this framework will make urban renewal programmes realizable which can be delivered hitch free to the people.
\end{abstract}

Keywords; Urban renewal, opposition, framework, citizens, sensitization.

\section{Introduction}

Part V of the Nigerian Urban and Regional Planning (NURP) law of 1992 provides that a local planning authority may declare an area an improvement area for the purpose of rehabilitating, renovating, and upgrading the physical environment, social facilities and infrastructure of the areas. Urban areas which are commonly declared improvement area by the local planning authority are the "sick areas" of the urban centres commonly referred to as slum areas. A slum is an area of advanced blight condition usually requiring clearance or rebuilding as the most effective corrective action (Omole, 2000). Slum refers to that part of the urban centre in which the houses and the neighbourhood facilities and services (where they exist) exhibit evidence of deterioration and the general outlook of the environment presents a picture of sub-standard structures, abject poverty and dilapidation (Agbonoga, 1998).

Remedial response to any slum area requires that a local planning authority whose sphere of authority contains such slum area prepares a local plan for the improvement of such area and after the plan has been approved by order published in the Gazatte, go ahead for the execution of the upgrading and improvement of the area. For the purpose of execution of urban renewal and upgrading plan, the NURP law provides in section 80(2) that the rehabilitation, renovation and upgrading may be brought about through the combined efforts of the residents of the area concerned, the control department and any other statutory bodies as may be relevant and complimentary to the rehabilitation, renovation or upgrading of the area. The law also provides for consultation and co-operation in improvement areas since in section 81(a) it demands that the urban renewal authority shall use its best endeavour to inform by such means as it deems fit, the slum area residents of (1) the purpose and contents of the proposed improvements (ii) the powers vested in the authority, and (iii) the facilities which would be made available and benefits to be derived after the urban renewal, (iv) hold meetings with local government officers or any other associations in the area for the purpose of (a) ascertaining the views of the residents on the proposed improvement and the exercise of powers relating thereto, (b) set up liaison or consultative committees between the authority and representatives of the residents to monitor the progress of the urban renewal or upgrading. The law goes further in section 81 subsections $2 \mathrm{a}, \mathrm{b}$ and $\mathrm{c}$ to enjoin urban renewal authority to hold regular meetings with the residents' committees, assist the residents to draw up and implement the urban renewal plans, advice the residents to take advantage of the improvements in their neighbourhood (NURP law, 1992). 


\section{Problem Definition}

The Nigerian Urban and Regional Planning (NURP) law made adequate provisions for the involvement of the citizens but studies on urban renewal programmes undertaken in Nigeria since 1960 independence reveal that the citizens and relevant bodies were always ignored which perhaps accounted for the failure of the urban renewal programmes to achieve their targets. Urban renewal authorities and policy makers in Nigeria had never sought or arranged for the effective involvement of slum inhabitants during urban renewal programmes for their abode. The residents were regarded as a basically passive crowd of objects who cannot respond to public issues or exert political control on public agencies (Back, 1962). The residents of slum areas can play active part in renewal process by their degree of co-operation, resistance and ultimate decision to change and accept changes in their abode. Non-involvement of the slum inhabitants resulted to the failure of well intentioned renewal projects in Nigeria, for instance, the non-involvement of Maroko residents during the proposed 1990 Maroko clearance project resulted to their resistance which is one of the factors that frustrated the scheme till date.

Similarly, Onibokun (1985) reports about the proposed renewal programmes for some parts of Ibadan which woefully failed because the people violently revolted against them and immediately planned for a show down if government carried out the renewal programmes. Government was compelled to drop the idea. In Port Harcourt, the story is similar because the planned upgrading programme for the central areas was paralyzed and halted because of mass riot by the residents and other stakeholders.

One outstanding reason often adduced for non-involvement of citizens in urban renewal programmes in Nigeria relates to non-existence of well articulated framework and modalities for citizens involvement. Because of this, it was not easy to determine how and when to involve them and the procedure with which to procure their involvement. The major aim of this paper is to address the problems of how and when to involve the relevant stakeholders, organizations and institutions and the modalities for securing their involvement and participation during urban renewal programmes particularly in developing nations such as Nigeria. The framework is an outcome of the pilot studies on Coal Camp urban renewal proposal in Enugu city, Nigeria, as part of a Ph.D programme on environmental management.

\section{Coal Camp Community}

Coal Camp Community is one of the layouts that make up the Enugu City which is situated at the extreme west of the city where there are workable coal seams which outcrop to the surface. It was established in 1918 for the indeginous coal miners but currently inhabited predominantly by automobile spare parts sellers and automobile parts fabricators and repairers, though other pursuits are well represented. Due to old age, high population density which resulted to high housing densities without adequate infrastructures, facilities and amenities coupled with neglect, Coal Camp Community was one of the worrisome, slum areas in Enugu City. The population is currently being estimated to be 31,816 people (Nnamani, 2002) occupying about 4.12 hectares of land. It consists of Ogbete, Obed Camp (Ngenevu), Asata Mine Quarters, Agangwu, Tinker, Jamboree, New Site and 'Agrick' settlement and is one of the communities in Enugu North Local Government Council.

\section{Commencement of the Urban Renewal Project}

The first step was to ascertain the opinion of the residents concerning the proposed urban renewal project. This was achieved by the distribution of 530 pre-coded copies of questionnaire spread across all the sub-units in accordance with population distribution. All the copies of the questionnaire were collected and responses were analysed with chi-square $\left(\mathrm{X}^{2}\right)$ statistical model at 0.05 significant level. This was processed in form of hypothesis testing in which the Ho reads that the people of Coal Camp Community are not opposed to the renewal of their community. The calculated Chi square $\left(\mathrm{x}^{2}\right)$ index was 30.758 , which was more than the table value of 24.996 at 0.05 level of significance. This led to the rejection of Ho and acceptance of alternative hypothesis (Hi). The result showed that the residents of Coal Camp Community are opposed to the proposed renewal programme. Note that their opposition is an indication that the entry point strategy is inappropriate. The starting point ought to be public enlightenment, sensitization and consultation.

\section{Verification of Reasons for Opposition}

In spite of the faulty entry point, attempt was made to identify their reasons for opposition. To do this, another set of 530 copies of structured questionnaire were distributed as before. Respondents who consisted of landlords and master-traders were requested to scale 10 variables (which were grouped into social and economic factors) on a 5-point Likert scale corresponding to 5, for major problem, 4, for good problem, 3, for fairly a problem, 2, for minor problem and 1, for not a problem. The Actual Reason Index (ARI) as applied by Afon (2004) method was used to analyze the returned responses. The identified reasons are as follows; (i) that urban renewal will disrupt their economic activities, (ii) that urban renewal is too costly to execute, (iii) urban renewal takes too much time to accomplish, (iv) that it will inflict much hardship on the people, (v) that it will displace many people and (vi) that it will disorganize many households. 


\section{Sensitization and Enlightenment Strategy Programme}

The essence for identifying their reasons for opposition is to use the findings in designing and articulating sensitization and enlightenment strategies. This programme started with the stratification of residents into homogenous sub-sets and the invitation of five of their key members to a briefing session. The following groups were recognized; (i) landlords' welfare union, (ii) Residents (iii) Teachers, (iv) automobile parts dealers, (v) automobile repairers, (vi) welders and iron fabricators and (vii) market traders (shops, restaurants and alcohol parlour keepers).

\section{Briefing Session and Meetings}

Briefing session was arranged with the invited representatives of the various strata. After the briefing session, a total of three meetings were held during which pertinent urban renewal issues were extensively discussed with particular reference to the actual benefits and how their fears and interests will be amicably protected. Their reactions formed further inputs during subsequent sensitization campaigns.

During the last meeting most of them exhibited a glaring interest and zeal which made the meeting to be an interactive session. One major request by them was to enlarge attendance by inviting more residents and to give the programme a wider publicity. This led to the invitation of the following organizations to subsequent meetings (i) Ministries such as Works, Housing, Health, Education, Environment, Lands, Survey and Urban Planning, Youths, Culture and Sports. (ii) Parastatals such as Power Holding Company of Nigeria (PHCN), Enugu State Waste Management Authority (ESWAMA), Nigeria Postal Services (NIPOST), Nigerian Telecommunications (NITEL), Post Primary Schools Management Board (PPSMB), Enugu State Universal Basic Education Board (ESUBEB), Enugu State Housing Development Corporation (ESHDC), Central Police Station (CPS), Enugu North Local Government Council, Enugu based Radio and Television Houses and Print Media, Nigerian Coal Corporation (NCC), Nigerian Road Transport Owners and Workers (Enugu branch) and Enugu State Water Corporation (iii) Supportive Agencies such as Urban Development Bank (UDB), Federal Mortgage Bank (FMB), Representatives of Coal Camp in the State House of Assembly and Federal Constituency.

\section{Enlarged Inaugural Meeting}

All the listed establishments were invited to the enlarged meeting and all, except PPSMB, sent representative to the enlarged inaugural meeting. During this meeting, far reaching decisions were reached which included general agreement to pursue the renewal programme ambitiously, to take sensitization down to grassroots and more importantly the acceptance by the Urban Development Bank and FMB to offer soft loans on request. Besides this inaugural meeting, three other meetings were held and all the establishments were duely represented and both the stakeholders, residents and the various representatives showed enthusiasm and then called for more commitment and grassroot involvement. There was also an agreement on how the banks will recover their disbursed loans by running the resettlement estates and redeveloped residential houses for 20 years.

\section{Grass-root Sensitization and Enlightenment}

In order to sensitize all and sundry, the following strategies were adopted (i) distribution of handbills, (ii) pasting of posters at suitable places, (iii) use of the media for mass link programmes and (iv) holding of street meetings.

\section{Reports}

Reports from street meetings and Radio and Television link programmes indicated that greater majority of the residents and other stakeholders had embraced the essence of the renewal programme.

\section{Verification of Opinion Change}

Though, shared opinions during discussions indicated general acceptance of the objectives of the proposed urban renewal, it is very important to statistically prove change in the opinion of residents and other stakeholders after series of sensitization and enlightenment programmes. To achieve this, a total of 500 copies of questionnaire were designed and distributed to the six strata of the community out of which 489 copies were duely completed and returned. Chi-square $\left(\mathrm{x}^{2}\right)$ technique was used as analytical technique for this verification at 0.05 level of significance. The result accepted the $\mathrm{H}_{0}$ and as such rejected $\mathrm{H}_{1}$, meaning that they were no longer opposed to urban renewal of their community. This change of opinion was attributed to adequate sensitization and enlightenment propaganda. 


\section{Constitution of Urban Renewal Board (URB)}

It was then ripe to constitute Urban Renewal Board (URB) consisting of ministries, parastatals, supportive agencies, landlords, civil servants, traders, artisans, and house of assembly and lower house representatives. The URB liaised with the Enugu North Town Planning Authority to direct, plan and control the urban renewal programme progress.

\section{Constitution of Technical Committees}

The URB later resolved into eight technical committees, namely, central committee, data acquisition and processing committee, propaganda and public relations committee, works committee, development control committee, security committee, fund raising and disbursement committee and logistics committee. Each of the committees was assigned specific responsibilities in a way to avoid overlaps and gaps and to ensure full realization of the renewal action plan. The central committee served as the co-ordinating and monitoring body. The central committee consisted of major landlords, chairmen of trade unions, house of assembly representative, NCC representative, Ngwo Community representative, Vigilante organization chairman and NPF representative. Having secured the support and co-operation of the people, the URB through its committees embarked on detailed study of Coal Camp Community aimed at acquiring data for the urban renewal plan.

\section{Findings}

- Residents and stakeholders were initially steeped in conservatism and strongly opposed to renewal of their community,

- Their opinion positively changed after enlightenment, sensitization and consultation.

- Their co-operation and support were secured with enlightenment and sensitization,

- Their commitment increased when they were involved in all aspects of the renewal activities,

- Their involvement allayed their fears and thus became enthusiastic rather than taking actions that will frustrate the renewal programmes,

- When they were involved in the identification of their community's socio-economic, housing and environmental problems, they became anxious to contribute their resources to seek for solutions,

- They co-operated to choose preferred Renewal Action Plans (RAP) and specific renewal actions,

- They chose sites for resettlement programmes and types of resettlement structures and

- They also formed a neighbourhood leadership (URB) to organize the implementation exercise and to enforce behavioural restrictions.

Out of fear and misconception, residents of an area designated for urban renewal usually protests against the proposal and if not properly addressed may frustrate the aim. This has been the fate of most urban renewal programmes in Nigeria. The support and co-operation of residents can always be secured if properly sensitized and enlightened prior to commencement of urban renewal. Urban renewal will become more successful if the residents are giving the chance to sit side by side with the planning authority to discuss details of relevant issues. Democratization and collaborative approach to urban renewal programmes provide a sure way to urban renewal success.

\section{Recommendation}

Based on the findings, a procedural flow chart was articulated and is hereby recommended for adoption during urban renewal programmes for the inevitable purpose of involving the slum residents and other relevant bodies, (See Figure 1 ).

\section{[Figure 1 about here]}

\section{Conclusion}

This study is advocating the adoption of strategies which conceive urban renewal as a social planning process, which stimulate the interest of the grassroots and which elicit their support in achieving urban renewal goals. This is in recognition that urban renewal is meant for the people and is supposed to be a people oriented project. Democratic principles include that people should be given sufficient opportunity to have a say in the affairs that concern them (Sheng, 1982). Adoption of this framework will help to involve the citizens in urban renewal and thus make urban renewal projects realizable in Nigeria. 
Figure 1: Procedural Framework for Citizen Involvement for Urban Renewal Programme

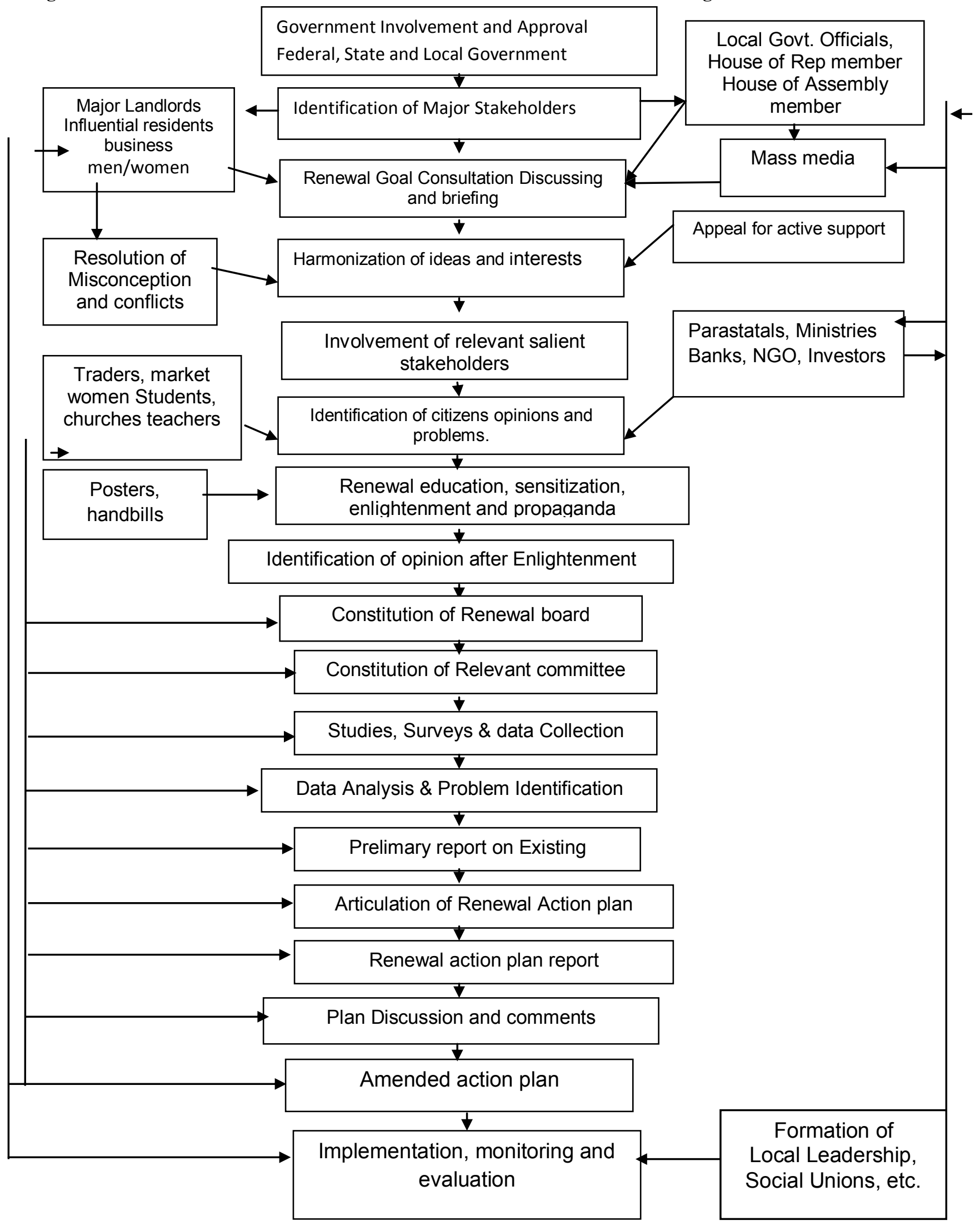

Source: Authors, 2008 


\section{References}

[1]. Afon, A. O. (2004), "Residents' Satisfaction Index in Selective Rehabilitation of an Urban Core Residential Area in Ogbomoso, Oyo State", Journal of the Nigerian Institute of Town Planners, pp 45 - 58.

[2]. Agbonoga, E. J. (1998), "Urban Renewal: A Key to Sustainable Nigerian Cities Revitalization in the21st Century", Conference Proceedings, Kaduna Polytechnic, College of Environmental Sciences, Oloyede, P. A. (ed.) pp 145 - 151.

[3]. Back, K. (1962), Slums, Projects and People: Social Psychological Problems of Relocation in Puerto Rico, Durhan, N. C. (ed), Duke University Press (Pubs).

[4]. Nnamani, C. (2002), "By the Hills and Valleys of Udi and Nsukka, the People, their Heritage, their Future," Tell News Magazine, No. 50, December, 16, pp $64-69$.

[5]. NURP Law (1992), The Nigerian Urban and Regional Planning Law, Decree No. 88. Part V.

[6]. Omole, F. K. (2000), Urban Renewal Process, Issues and Strategies, Concept Books and Publications Company, Nigeria Ltd, Lagos.

[7]. Onibokun, P. (1985), "Nigerian Cities, their Rehabilitation and Redevelopment", Housing in Nigeria, Onibokun, K. (ed), NISER, Ibadan.

[8]. Sheng, Y. K. (1982), “Access to Resources and Services as a Form of Participations”, Community for Improving Human Settlement, United Nations Centre for Human Settlements, Nairobi, United Nations Publications. 